\title{
EFEK ANTIDIABETES EKSTRAK AIR KULIT BUAH PISANG AMBON (Musa paradisiaca L.) TERHADAP MENCIT (Mus musculus) MODEL HIPERGLIKEMIA
}

\section{EFFECTS ANTIDIABETIC EXTRACT WATER OF THE FRUIT PEEL BANANAS (Musa paradisiaca L.) IN MICE (Mus musculus) MODELS OF HYPERGLYCEMIA}

\author{
Sri Indrawati ${ }^{1}$, Yuliet ${ }^{1}$, Ihwan ${ }^{1}$ \\ ${ }^{1}$ Jurusan Farmasi Fakultas MIPA UniversitasTadulako, Palu.
}

Received 30 Agustus 2015, Accepted 28 September 2015

\begin{abstract}
ABSTRAK
Pisang ambon (Musa paradisiaca L.) merupakan salah satu jenis pisang yang banyak dikonsumsi masyarakat Indonesia. Selain daging buah yang memiliki gizi yang tinggi, kulit pisang juga memiliki aktivitas antioxidant. Antioksidan memiliki kemampuan dalam mengurangi kerusakan oksidatif pada tubuh penderita diabetes melitus. Oleh karena itu, penelitian ini bertujuan untuk mengetahui aktivitas antidiabetes ekstrak air kulit buah pisang ambon dan menentukan dosis efektif ekstrak air kulit buah pisang ambon sebagai antidiabetes terhadap mencit model hiperglikemia. Penelitian ini menggunakan mencit jantan yang sebelumnya telah diinduksi dengan aloksan $50 \mathrm{mg} / \mathrm{kgBB}$ secara intravena. Mencit-mencit tersebut kemudian dibagi menjadi lima kelompok. Dua kelompok pertama mendapat Na.CMC 0,5\% (kontrol negatif), Glibenklamid 0,65 mg/kgBB (kontrol positif), sedangkan ketiga kelompok lainnya mendapat ekstrak air kulit buah pisang ambon dengan dosis 400, 800, dan $1200 \mathrm{mg} / \mathrm{kgBB}$. Hasil data yang diperoleh dianalisis secara statistik menggunakan ANOVA (analysis of variance) pada taraf kepercayaan 95\% dengan parameter selisih penurunan kadar glukosa darah. Hasil penelitian menunjukkan bahwa ekstrak air kulit buah pisang ambon memiliki efek antidiabetes dan dosis $400 \mathrm{mg} / \mathrm{kgBB}$ merupakan dosis efektif sebagai antidiabetes pada mencit model hiperglikemia yang sebanding dengan glibenklamid.
\end{abstract}

Kata kunci : Pisang Ambon, Antidiabetes, Ekstrak Air, Aloksan.

\begin{abstract}
Pisang Ambon (Musa paradisiaca L.) is one type of bananas usually consumed by Indonesian people. Besides its flesh which has high nutrition, its peels also has antioxidant activity. Antioxidants has the ability to reduce oxidative damage in people's body with diabetes mellitus. Therefore, this study aimed to determine the antioxidant activity of the aqueous extract of Pisang Ambon peels and to determine it's effective dose as an antidiabetic agent in hyperglycemic mice. This study used male mice which all have been intravenously induced with alloxan at a dose of $50 \mathrm{mg} / \mathrm{kgBW}$. They were then divided into five groups. The first two groups got $\mathrm{Na}$ CMC $0.5 \%$ (negative control) and glibenclamide $0.65 \mathrm{mg} / \mathrm{kgBW}$ (positive control), while the other three got the aqueous extract of Pisang Ambon peels successively at doses of 400, 800, and $1200 \mathrm{mg} / \mathrm{kgBW}$. The data were statistically analyzed using ANOVA (Analysis of Variance) at 95\% confidence interval with parameter of blood glucose levels difference between before and after treatment. The results showed that the aqueous extract of Pisang Ambon peels had antidiabetic activity at an effective dose of $400 \mathrm{mg} / \mathrm{kgBW}$ in hyperglycemic mice which was comparable to glibenclamide.
\end{abstract}

Keywords: Pisang Ambon peels, Antidiabetic, Aqueous Extract, Alloxan.

*Corresponding author : Sri Indrawati sriindrawati95@yahoo.co.id 


\section{PENDAHULUAN}

Diabetes Melitus (DM) merupakan gangguan metabolisme yang ditandai dengan resistensi terhadap aksi insulin, sekresi insulin yang tidak memadai atau keduanya. Manifestasi klinis dari gangguan ini adalah hiperglikemia (Dipiro, 2005). Terdapat dua kategori utama diabetes melitus yaitu diabetes tipe 1 yang disebut insulin dependent diabetes melitus ditandai dengan kurangnya produksi insulin dan diabetes tipe 2 yang disebut non insulin dependent diabetes melitus disebabkan penggunaan insulin yang kurang efektif oleh tubuh. Diabetes tipe 2 merupakan $90 \%$ dari seluruh kejadian diabetes. Estimasi International Diabetes Federation (IDF), terdapat 382 juta orang yang hidup dengan diabetes didunia pada tahun 2013. Pada tahun 2035 jumlah tersebut diperkirakan akan meningkat menjadi 592 juta orang (Anonim, 2014).

Pada dasarnya ada dua pendekatan dalam penatalaksanaan diabetes, yang pertama pendekatan nonfarmakologi atau tanpa obat dan yang kedua adalah pendekatan farmakologi atau pendekatan dengan obat (Anonim, 2005). Namun, selain obat-obatan sintetik, diabetes melitus dapat diatasi dengan obat alami dengan memanfaatkan tanaman berkhasiat obat (Hembing W., 2004).

Pisang merupakan tanaman yang banyak tumbuh di Indonesia dan merupakan buah yang banyak dikonsumsi masyarakat Indonesia disemua kalangan, salah satu jenis pisang yaitu pisang ambon (Musa paradisiaca L.). Pisang ambon memiliki khasiat sebagai antidiabetes (Imam, 2011). Bagian tanaman yang dimanfaatkan yaitu kulit buah. Hasil penelitian sebelumnya, ekstrak air kulit buah pisang ambon dosis $800 \mathrm{mg} / \mathrm{Kg}$ BB memiliki efek hipoglikemik terhadap mencit model hiperglikemik dengan metode toleransi glukosa. Menurut Someya (2002) dalam Peni Sri (2012), kulit pisang memiliki aktivitas antioksidan lebih tinggi dibandingkan daging buahnya. Antioksidan mampu mengontrol kadar glukosa darah dan mencegah komplikasi diabetes melitus (Widowati, 2008). Jenis senyawa antioksidan yang dapat diisolasi dari kulit buah pisang yaitu flavonoid (Peni Sri, 2012).

Berdasarkan uraian diatas, maka peneliti tertarik untuk melakukan pengujian efek antidiabetes ekstrak air kulit buah pisang ambon (Musa paradisiaca L.) pada model hewan uji hiperglikemia. Hewan uji yang digunakan dalam penelitian ini yaitu mencit (Mus musculus) dengan metode uji diabetes induksi aloksan.

\section{METODE PENELITIAN Jenis Penelitian}

Jenis penelitian ini adalah eksperimen laboratorium dengan rancangan penelitian acak lengkap pola searah. Pengujian efek antidiabetes dilakukan dengan metode induksi aloksan. Kelompok perlakuan dibagi menjadi 5 kelompok uji, masing-masing terdiri dari 4 ekor mencit sebagai model hewan diabetes. Kemudian diberikan perlakuan sesuai kelompok uji.

\section{Waktu dan Tempat Penelitian}

Penelitian ini dilakukan sejak bulan Mei sampai Oktober 2015, bertempat di Laboratorium Agroteknologi Fakultas Pertanian dan di Laboratorium FarmakologiBiofarmasi Jurusan Farmasi, FMIPA Universitas Tadulako.

\section{Persiapan Bahan Uji}

Bahan uji yang digunakan dalam penelitian ini adalah kulit buah pisang ambon (Musa paradisiaca L.) diperoleh dari Kecamatan Dolo Kabupaten Sigi. Identifikasi tanaman dilakukan di UPT Sumber Daya Hayati Sulawesi Tengah. Kulit buah pisang dibersihkan dengan air dan ditiriskan, lalu dirajang berukuran kecil. Kulit buah pisang 350 gram diektraksi dengan aquadest $1000 \mathrm{ml}$. Ekstrak air yang diperoleh disaring dan dikeringkan dengan freeze dryer hingga diperoleh ekstrak kering di Laboratorium Agroteknologi Fakultas Pertanian 


\section{Uji Penapisan Fitokimia (Harbone, 1987)}

Ekstrak air kulit pisang ambon yang telah didapatkan kemudian diuji kualitatif terhadap adanya senyawa flavonoid, fenolik, saponin, steroid, terpenoid, alkaloid, dan tannin di Laboratorium FarmakognosiFitokimia Jurusan Farmasi Fakultas MIPA Universitas Tadulako.

\section{Pengujian Aktivitas Antidiabetes}

Hewan uji mencit (Mus musculus) yang digunakan berjumlah 20 ekor dan masing-masing kelompok terdiri dari 4 ekor mencit yang dibagi secara acak. Mencit yang berumur 2-3 bulan terlebih dahulu diadaptasi selama 7 hari. Kemudian dipuasakan selama 16 jam dan dilakukan pengukuran kadar glukosa darah awal (T0) dari vena ekor untuk memastikan mencit yang digunakan dalam keadaan normal. Semua hewan uji diinduksikan aloksan $50 \mathrm{mg} / \mathrm{Kg} \mathrm{Bb}$ secara intravena di bagian ekor mencit dan dilakukan pengukuran kadar glukosa darah hiperglikemia awal pada hari ke tiga setelah induksi. Apabila kadar glukosa darah puasa > $200 \mathrm{mg} / \mathrm{dL}$ mencit dianggap sudah mengalami hiperglikemia. Kemudian diberikan perlakuan sesuai kelompok dengan pemberian bahan uji selama 2 minggu dan dilakukan pengukuran kadar glukosa darah pada hari ke 7, 9, 11 dan 18. Data hasil perlakuan dikumpulkan dan diolah untuk dilakukan analisis data.

\section{Analisis Data}

Data berupa selisih penurunan kadar glukosa darah dianalisis secara statistik denganone way anova pada taraf kepercayaan $95 \%$, sebelumnya diuji homogenitasnya (uji Levene) dan kenormalan distribusinya dengan menggunakan uji Saphiro Wilk. Apabila data homogen dan terdistribusi normal maka dilakukan uji analisis varians (ANOVA) satu arah dilanjutkan dengan uji Post Hoc Duncan untuk mengetahui kelompok perlakuan yang berbeda signifikan dibanding kelompok perlakuan lainnya.

\section{HASIL DAN PEMBAHASAN \\ Hasil}

Hasil rendemen yang diperoleh dari proses ekstraksi sebesar 4,06\%. Berdasarkan penapisan fitokimia yang telah dilakukan diperoleh hasil bahwa ekstrak air kulit buah pisang ambon positif mengandung senyawa flavonoid, fenolik, saponin dan tanin, sedangkan negative terhadap alkaloid. Senyawa-senyawa inilah yang berperan dalam memberikan khasiat dan efek biologis.

Hasil pengukuran kadar glukosa darah mencit dilakukan sebelum perlakuan, setelah induksi dan setelah perlakuan yaitu pada hari ke 7, 9, 11, dan 18 dapat dilihat pada Tabel 1 berikut.

Tabel 1. Kadar rata-rata glukosa darah mencit

\begin{tabular}{|c|c|c|c|c|c|c|}
\hline \multirow{2}{*}{$\begin{array}{l}\text { Kelompok } \\
\text { perlakuan }\end{array}$} & \multicolumn{6}{|c|}{ Kadar glukosa darah (mg/dL) } \\
\hline & H 0 & $\mathrm{H} 4$ & H 7 & H 9 & H 11 & H 18 \\
\hline $\begin{array}{c}\text { Kontrol } \\
\text { negatif } \\
\mathrm{Na} \mathrm{CMC} \\
0,5 \%\end{array}$ & $\begin{array}{c}94,25 \\
\pm \\
15,79\end{array}$ & $\begin{array}{c}392,2 \\
\pm \\
139,83\end{array}$ & $\begin{array}{c}432,50 \\
\pm \\
116,96\end{array}$ & \multicolumn{2}{|c|}{$\begin{array}{c}456,00 \pm 438,75 \pm \\
78,11 \quad 68,05\end{array}$} & $\begin{array}{c}538,75 \\
\pm \\
69,02\end{array}$ \\
\hline $\begin{array}{c}\text { Kontrol } \\
\text { positif } \\
\text { Glibenklami } \\
\text { d } \\
0,65 \mathrm{mg} / \mathrm{Kg} \\
\mathrm{BB}\end{array}$ & $\begin{array}{c}139,00 \\
\pm \\
39,06\end{array}$ & $\begin{array}{c}518,50 \\
\pm \\
113,63\end{array}$ & $\begin{array}{c}343,00 \\
\pm \\
113,63\end{array}$ & \multicolumn{2}{|c|}{$\begin{array}{c}355,25 \pm 296,00 \pm \\
123,48 \quad 72,84\end{array}$} & $\begin{array}{c}243,00 \\
\pm \\
95,65\end{array}$ \\
\hline $\begin{array}{c}\mathrm{DE} 400 \\
\mathrm{mg} / \mathrm{Kg} \mathrm{BB}\end{array}$ & $\begin{array}{c}90,50 \\
\pm \\
15,67\end{array}$ & $\begin{array}{l}419,25 \\
\pm 63,78\end{array}$ & $\begin{array}{c}327,50 \\
\pm \\
78,15\end{array}$ & \multicolumn{2}{|c|}{$\begin{array}{c}280,50 \pm 238,25 \pm \\
82,05 \quad 96,21\end{array}$} & $\begin{array}{c}153,75 \\
\pm \\
71,28\end{array}$ \\
\hline $\begin{array}{c}\text { DE } 800 \mathrm{mg} / \\
\mathrm{Kg} \mathrm{BB}\end{array}$ & $\begin{array}{c}111,00 \\
\pm \\
23,76\end{array}$ & $\begin{array}{l}541,50 \\
\pm 97,34\end{array}$ & $\begin{array}{c}417,75 \\
\pm \\
85,31\end{array}$ & $\begin{array}{c}390,25 \pm \\
87,18\end{array}$ & $\begin{array}{r}266,75 \\
\pm 56,34\end{array}$ & $\begin{array}{c}147,50 \\
\pm \\
65,44\end{array}$ \\
\hline $\begin{array}{c}\text { DE } 1200 \\
\mathrm{mg} / \mathrm{Kg} \mathrm{BB}\end{array}$ & $\begin{array}{c}102,25 \\
\pm \\
8,73\end{array}$ & $\begin{array}{c}478,50 \\
\pm \\
153,26\end{array}$ & $\begin{array}{c}290,50 \\
\pm \\
125,10\end{array}$ & $\begin{array}{c}246,25 \pm \\
167,31\end{array}$ & $\begin{array}{c}164,25 \\
\pm \\
103,55\end{array}$ & $\begin{array}{c}129,75 \\
\pm \\
35,67\end{array}$ \\
\hline
\end{tabular}

Keterangan :

H0 : Kadar glukosa darah awal

H4 : Kadar glukosa darah setelah pemberian induksi aloksan 50 $\mathrm{mg} / \mathrm{kgBB}$

H7 : Kadar glukosa darah setelah 3 hari pemberian sediaan uji

H9 : Kadar glukosa darah setelah 5 hari pemberian sediaan uji

H11 : Kadar glukosa darah setelah 7 hari pemberian sediaan uji

H18 : Kadar glukosa darah setelah 14 hari pemberian sediaan uji

DE : Kelompok ekstrak kulit buah pisang ambon (sesuai dosis) 


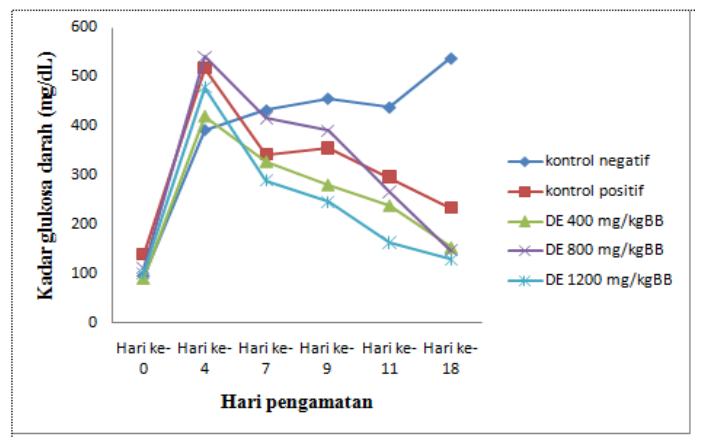

Gambar 1. Profil rerata kadar glukosa darah mencit

Keterangan:

Kontrol negatif : Kelompok perlakuan yang diberikan Na CMC 0,5\%

Kontrol positif : Kelompok perlakuan yang diberikan glibenklamid $0,65 \mathrm{mg} / \mathrm{kgBB}$

DE : Kelompok ekstrak kulit buah pisang ambon (sesuai dosis)

Tabel 2. Selisih penurunan rerata kadar glukosa darah

\begin{tabular}{|c|c|c|c|c|}
\hline \multirow{2}{*}{$\begin{array}{l}\text { Kelompok } \\
\text { perlakuan }\end{array}$} & \multicolumn{4}{|c|}{$\begin{array}{l}\text { Selisih penurunan rerata kadar glukosa darah dan } \\
\text { standar deviasi }\end{array}$} \\
\hline & $\Delta_{1}$ & $\Delta_{2}$ & $\Delta_{3}$ & $\Delta_{4}$ \\
\hline $\begin{array}{c}\text { Kontrol } \\
\text { negatif }\end{array}$ & $\begin{array}{c}-40,25 \\
\pm \\
24,78^{\mathrm{a}}\end{array}$ & $\begin{array}{c}-63,75 \\
\pm \\
78,42^{\mathrm{a}}\end{array}$ & $\begin{array}{c}-46,50 \\
\pm \\
171,59^{a}\end{array}$ & $\begin{array}{c}-146,50 \\
\pm \\
123,34^{\mathrm{a}}\end{array}$ \\
\hline $\begin{array}{c}\text { Kontrol } \\
\text { positif }\end{array}$ & $\begin{array}{c}175,50 \\
\pm \\
88,14^{\mathrm{b}}\end{array}$ & $\begin{array}{c}163,25 \\
\pm \\
94,43^{b}\end{array}$ & $\begin{array}{c}222,50 \\
\pm \\
74,63^{b}\end{array}$ & $\begin{array}{c}275,50 \\
\pm \\
100,06^{b}\end{array}$ \\
\hline $\begin{array}{c}\mathrm{DE} 400 \\
\mathrm{mg} / \mathrm{kgBB}\end{array}$ & $\begin{array}{c}91,75 \\
\pm \\
77,89^{b}\end{array}$ & $\begin{array}{c}138,75 \\
\pm \\
91,31^{b}\end{array}$ & $\begin{array}{c}181.00 \\
\pm \\
113,94^{\mathrm{b}}\end{array}$ & $\begin{array}{c}265,50 \\
\pm \\
91,44^{b}\end{array}$ \\
\hline $\begin{array}{c}\mathrm{DE} 800 \\
\mathrm{mg} / \mathrm{kgBB}\end{array}$ & $\begin{array}{c}123,75 \\
\pm \\
50,20^{\mathrm{b}}\end{array}$ & $\begin{array}{c}151,25 \\
\pm \\
44,51^{b}\end{array}$ & $\begin{array}{c}274,75 \\
\pm \\
111,10^{b}\end{array}$ & $\begin{array}{c}394.00 \\
\pm \\
127,41^{\mathrm{b}}\end{array}$ \\
\hline $\begin{array}{l}\mathrm{DE} 1200 \\
\mathrm{mg} / \mathrm{kgBB}\end{array}$ & $\begin{array}{c}188.00 \\
\pm \\
130,37^{b}\end{array}$ & $\begin{array}{c}232,25 \\
\pm \\
194,50^{b}\end{array}$ & $\begin{array}{c}314,25 \\
\pm \\
131,22^{\mathrm{b}}\end{array}$ & $\begin{array}{c}348,75 \\
\pm \\
152,75^{b}\end{array}$ \\
\hline
\end{tabular}

Keterangan:

$\Delta 1$ : Selisih penurunan kadar glukosa darah pada hari ke-4 dan hari ke-7

$\Delta 2$ : Selisih penurunan kadar glukosa darah pada hari ke-4 dan hari ke-9

$\Delta 3$ : Selisih penurunan kadar glukosa darah pada hari ke-4 dan hari ke-11

$\Delta 4$ : Selisih penurunan kadar glukosa darah pada hari ke-4 dan hari ke-18

Kontrol negatif : Kelompok perlakuan yang diberikan Na CMC 0,5\%

Kontrol positif: Kelompok perlakuan yang diberikan glibenklamid $0,65 \mathrm{mg} / \mathrm{kgBB}$
DE : Kelompok ekstrak kulit buah pisang ambon (sesuai dosis)

- Abjad yang sama menunjukkan adanya perbedaan yang tidak signifikan.

- Abjad yang berbeda menunjukkan adanya perbedaan yang signifikan.

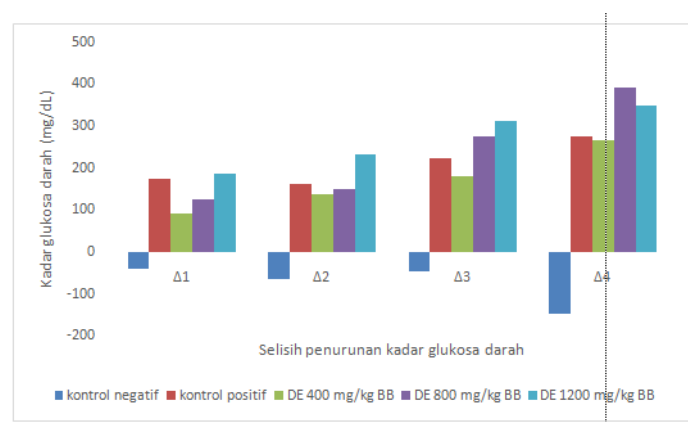

Gambar 2. Grafik selisih penurunan kadar glukosa darah

Keterangan:

$\Delta 1$ : Selisih penurunan kadar glukosa darah pada hari ke-4 dan hari ke-7

$\Delta 2$ : Selisih penurunan kadar glukosa darah pada hari ke-4 dan hari ke-9

$\Delta 3$ : Selisih penurunan kadar glukosa darah pada hari ke-4 dan hari ke-11

$\Delta 4$ : Selisih penurunan kadar glukosa darah pada hari ke-4 dan hari ke-18

Kontrol negatif : Kelompok perlakuan yang diberikan Na CMC 0,5\%

Kontrol positif : Kelompok perlakuan yang diberikan glibenklamid $0,65 \mathrm{mg} / \mathrm{kg}$ BB

\section{Pembahasan}

Penelitian ini menggunakan ekstrak air kulit buah pisang ambon (Musa paradisiaca L.) yang telah dilakukan identifikasi untuk memastikan bahwa benar tanaman yang digunakan adalah kulit buah pisang ambon (Musa paradisiaca L.) . Ekstrak air kulit buah pisang ambon diperoleh dari proses ekstraksi kulit buah pisang ambon sebanyak 350 gram yang dididihkan dalam $1000 \mathrm{ml}$ aquadest selama 5 menit. Perebusan ini dimaksudkan untuk menginaktifkan enzim polifenoloksidase yang dapat menyebabkan komponen polifenol dalam kulit pisang mengalami kerusakan (Peni Sri, 2012). Ekstrak air yang didapatkan 
sebanyak 14,2 gram dengan rendemen yang diperoleh sebesar 4,06\%.

Penapisan fitokimia dilakukan dengan tujuan untuk mengetahui golongan senyawa yang terkandung dalam ekstrak uji yang digunakan. Hasil penapisan yang diperoleh menunjukkan bahwa ekstrak air kulit buah pisang ambon memberikan hasil yang positif adanya golongan senyawa flavonoid, fenolik, saponin dan tanin.

Pengujian hipoglikemik pada penelitian ini dilakukan dengan metode induksi aloksan pada mencit jantan normal dengan kisaran kadar glukosa darah antara $62-175 \mathrm{mg} / \mathrm{dL}$ (Malole \& Pramono, 1989). Pengujian ini menggunakan mencit karena mudah didapat dan mudah ditangani, murah, dan telah ada penelitian sebelumnya yang berhasil. Mencit jantan dipilih karena memiliki kondisi hormonal yang lebih stabil dibanding betina dimana mencit jantan tidak mengalami siklus estrus, masa kehamilan dan menyusui yang mempengaruhi psikologis hewan uji. Mencit jantan pada usia 2-3 bulan adalah mencit dewasa muda yang mempunyai keadaan fisiologik yang optimum. Mencit yang digunakan terlebih dahulu diadaptasi selama 7 hari agar dapat menyesuaikan diri dengan lingkunganya selama penelitian berlangsung.

Hewan uji diukur kadar glukosa darah awal dan hasil pengukuran menunjukkan bahwa kadar glukosa darah masing-masing mencit berkisar antara $(90,50 \pm 15,76) \quad-$ $(139,00 \pm 39,06) \mathrm{mg} / \mathrm{dL}$ maka dapat dipastikan bahwa mencit yang digunakan dalam keadaan normal, selanjutnya diberikan induksi aloksan. Aloksan adalah senyawa analog glukosa yang bersifat toksik dimana pengubahannya menjadi ion radikal hidroksi dapat mengakibatkan kematian sel $\beta$ pankreas yang kemudian menghambat sekresi insulin.

Aloksan dipilih sebagai diabetogen karena aloksan didalam tubuh mengalami metabolisme oksidasi reduksi menghasilkan radikal bebas dan radikal aloksan. Radikal ini mengakibatkan kerusakan pankreas (Szkudelski, 2001). Pemilihan aloksan sebagai agen penginduksi diabetes dikarenakan kemampuannya untuk membuat hewan uji terkondisi sama seperti pasien diabetes melitus. Selain itu, keadaan hiperglikemia pada hewan uji dapat dicapai dalam waktu yang cukup singkat yaitu 2-3 hari setelah induksi aloksan.

Uji pendahuluan dilakukan untuk memperoleh dosis efektif yang akan digunakan. Rentang dosis aloksan yang harus diberikan kepada hewan uji untuk menghasilkan keadaan diabetes aloksan sangat sempit. Apabila dosis sedikit lebih besar maka hewan uji dapat mengalami toksik pada bagian sel tubulus ginjal atau bahkan kematian. Pada penggunaannya, secara umum aloksan dengan dosis $65 \mathrm{mg} / \mathrm{kg}$ BB dapat menyebabkan hiperglikemia pada tikus (Szkudelski, 2001), namun hewan uji yang berbeda dan kondisi yang berbeda akan menghasilkan dosis yang berbeda. Hasil orientasi dosis menunjukkan hewan uji yang diberikan dosis $50 \mathrm{mg} / \mathrm{kg}$ BB secara intravena telah mampu memberikan keadaan hiperglikemia.

Hari keempat setelah diinduksikan aloksan diamati efek hiperglikemia yang terjadi pada hewan uji, karena bisa terjadi kemungkinan hewan uji hiperglikemia menjadi normal kembali sebelum mengalami hiperglikemia permanen. Hal ini karena fluktuasi kadar glukosa darah selama 24-36 jam, hewan uji dapat mengalami hipoglikemia dan hiperglikemia secara bergantian. Bila hal tesebut terjadi maka hewan uji akan diinduksikan aloksan kembali dengan dosis yang sama.

Pada hari pengukuran setelah penginduksian, peningkatan kadar glukosa darah hewan uji yang hiperglikemia bervariasi dengan kisaran kadar glukosa darah antara $(392,25 \pm 139,83)-(541,50 \pm 97,34) \mathrm{mg} / \mathrm{dL}$. Hal ini karena daya tahan tubuh masing-masing hewan uji yang berbeda terhadap aloksan yang menyebabkan kondisi diabetes yang variatif. Variasi data yang cukup beragam ini juga terlihat dari simpangan masing-masing kelompok yang jauh lebih besar dibandingkan standar deviasi keadaan glukosa darah awal. Hewan uji yang mengalami hiperglikemia 
dapat terlihat dengan ciri seperti kadar glukosa tinggi, berat badan menurun, dan keadaan poliuria pada hewan uji yang terlihat pada kondisi kandang hewan yang selalu lembab.

Hewan uji hiperglikemia kemudian diberikan perlakuan sesuai kelompok selama 14 hari. Pada penelitian ini diberikan 3 kelompok perlakuan yaitu kontrol positif, kontrol negatif dan kontrol perlakuan (ekstrak sesuai dosis). Kontrol positif dalam penelitian ini adalah glibenklamid, hal ini diperlukan untuk melihat pengaruh obat antidiabetik oral yang telah terbukti khasiatnya untuk menurunkan kadar glukosa darah. Glibenklamid merupakan obat golongan sulfonilurea generasi kedua, yang sering digunakan pada pasien diabetes melitus. Glibenklamid tidak larut dalam air sehingga disuspensikan dengan zat pensuspensi $\mathrm{Na}$ CMC 0,5\%.Dosis glibenklamid yang digunakan adalah $0,65 \mathrm{mg} / \mathrm{kg}$ BB. Dosis tersebut digunakan berdasarkan dosis efektif oral pada manusia yaitu $5 \mathrm{mg} / \mathrm{hari}$ yang kemudian dikonversi ke dosis mencit. Alasan pemilihan $\mathrm{Na} \mathrm{CMC}$ dikarenakan sistem pencernaan mencit tidak memiliki enzim selulase. Maka penggunaan Na CMC tidak akan berpengaruh pada kadar glukosa darah. Akan tetapi untuk menghilangkan pengaruh $\mathrm{Na}$ CMC pada hasil penelitian maka kelompok kontrol negatif diberikan suspensi $\mathrm{Na}$ CMC sebagai pengganti bahan uji. Kontrol negatif yang diinduksi dengan aloksan sehingga menjadi diabetes diperlukan untuk mengetahui penurunan kadar glukosa darah. Bahan uji yang digunakan dalam penelitian ini yaitu ekstrak airkulit buah pisang ambon dengan dosis $400 \mathrm{mg} / \mathrm{kg} \mathrm{BB}, 800 \mathrm{mg} / \mathrm{kg} \mathrm{BB}$ dan 1200 $\mathrm{mg} / \mathrm{kg} \mathrm{BB}$, pemberian bahan uji satu kali sehari peroral dengan menggunakan sonde lambung selama 14 hari berturut-turut, dan dilakukan pengukuran kadar glukosa darah pada hari ke 7, 9, 11, dan 14 .

Hasil rata-rata kadar glukosa darah dapat dilihat pada Tabel 1. Data pengukuran menunjukkan adanya penurunan kadar glukosa darah yang beragam pada setiap kelompok mulai hari ke-7 hingga hari ke-18 yang menyebabkan data memiliki standar deviasi yang cukup besar. Hal ini disebabkan karena keadaan patofisiologik hewan uji, kemampuan untuk mengabsorbsi bahan uji dan kemampuan hewan uji untuk beradaptasi dengan kondisi hiperglikemia.

Profil rerata kadar glukosa darah mencit (Gambar 1) terlihat bahwa kontrol positif dan kontrol uji menunjukkan penurunan kadar glukosa darah secara bertahap. Sedangkan kontrol negatif masih mengalami hiperglikemia. Sehingga dapat dilihat bahwa setelah pemberian perlakuan, semua kelompok mengalami penurunan kadar glukosa darah kecuali kontrol negatif.

Hasil uji Anova digunakan untuk mengetahui adanya perbedaan penurunan kadar glukosa darah pada tiap kelompok. Pada perlakuan hari ke 7, 9, 11 dan 18 kelompok kontrol negatif, kontrol positif dan kontrol uji dosis $400 \mathrm{mg} / \mathrm{kg} \mathrm{BB}, 800 \mathrm{mg} / \mathrm{kg} \mathrm{BB}$, dan 1200 $\mathrm{mg} / \mathrm{kg}$ BB menunjukkan hasil yang berbeda signifikan dengan nilai $\mathrm{p}$ masing-masing berturut-turut $0,010,0,023,0,008$, dan 0,000 $(\mathrm{p}<0,05)$. Sehingga uji dilanjutkan dengan Post Hoc Duncan untuk mengetahui kelompok perlakuan yang berbeda signifikan dibanding kelompok perlakuan lainnya. Hasil uji lanjut Duncan terhadap selisih penurunan kadar glukosa darah menunjukkan bahwa kontrol negatif berbeda signifikan dengan kontrol positif dan kontrol uji ekstrak air kulit buah pisang ambon dosis $400 \mathrm{mg} / \mathrm{kg} \mathrm{BB}, 800 \mathrm{mg} / \mathrm{kg}$ $\mathrm{BB}$, dan $1200 \mathrm{mg} / \mathrm{kg} \mathrm{BB}$. Hal ini berarti, glibenklamid dan ketiga ekstrak uji mempunyai efek antidiabetes.

Hasil uji statistik selisih penurunan kadar glukosa darah pada hari ke 7, 9, 11, dan 18 menunjukkan adanya perbedaan yang tidak signifikan antara kelompok kontrol positif glibenklamid dan kontrol bahan uji ekstrak air kulit buah pisang ambon dosis $400 \mathrm{mg} / \mathrm{kg} \mathrm{BB}$, $800 \mathrm{mg} / \mathrm{kg} \mathrm{BB}$, dan $1200 \mathrm{mg} / \mathrm{kg} \mathrm{BB}$.

Peningkatan dosis obat seharusnya meningkatkan respon yang sebanding dengan dosis yang ditingkatkan. Namun dengan meningkatnya dosis, peningkatan respon pada akhirnya akan menurun karena sudah tercapai 
dosis optimum. Hal ini sering terjadi karena komponen senyawa pada bahan obat alam tidaklah tunggal melainkan terdiri dari berbagai macam senyawa bioaktif yang saling bekerja sinergis menimbulkan efek.

Glibenklamid memberikan efek hipoglikemik dengan bekerja sebagai insulin secretagogues yang merangsang sekresi insulin. Rangsangannya melalui interaksi dengan ATP- sensitive $\mathrm{K}$ Channel yang menimbulkan depolarisasi sehingga ion $\mathrm{Ca} 2+$ masuk kedalam sel beta pankreas, serta merangsang sekresi insulin konsentrasi plasma puncak dicapai setelah 2-4 jam setelah pemberian.

Ekstrak air kulit buah pisang ambon memiliki efek hipoglikemik karena adanya efek sinergis senyawa bioaktif yang terkandung antara lain flavonoid, fenolik, saponin dan tanin. Kulit buah pisang memiliki aktivitas sebagai antioksidan. Berdasarkan penelitian Someya (2002) dalam Peni Sri (2012), jenis senyawa antioksidan yang dapat diisolasi dari kulit buah pisang yaitu flavonoid. Kulit buah pisang mengandung aktivitas antioksidan yang lebih tinggi dibandingkan dengan daging buahnya. Antioksidan bermanfaaat dapat mengurangi kerusakan oksidatif pada penderita diabetes sehingga mampu mengontrol kadar glukosa darah dan mencegah komplikasi (Widowati, 2008).

Saponin dapat memberikan efek hipoglikemik karena mampu meregenerasi pankreas yang menyebabkan adanya peningkatan jumlah sel $\beta$ pankreas dan pulaupulau langerhans sehingga sekresi insulin akan mengalami peningkatan. Peningkatan sekresi insulin tersebut akan membantu penurunan kadar glukosa darah (Firdous et., al., 2009). Tanin dapat menurunkan kadar glukosa darah dengan cara menangkap radikal bebas dan mengurangi peningkatan stres oksidatif pada penderita diabetes sehingga mampu mengontrol kadar glukosa darah (Widowati, 2008).

Peningkatan dosis umunya sebanding dengan meningkatkan efek yang diberikan, namun hasil yang didapatkan bahwa ekstrak dengan dosis $400 \mathrm{mg} / \mathrm{kg} \mathrm{BB}, 800 \mathrm{mg} / \mathrm{kg} \mathrm{BB}$ dan $1200 \mathrm{mg} / \mathrm{kg}$ BB menunjukkan perbedaan yang tidak signifikan secara statistik terhadap penurunan kadar glukosa darah. Sehingga ekstrak dengan dosis $400 \mathrm{mg} / \mathrm{kg}$ BB telah mampu memberikan efek hipoglikemik (antidiabetes) terhadap mencit model hiperglikemia.

\section{DAFTAR PUSTAKA}

Anonim. (2005). Pharmaceutical Care Untuk Penyakit Dibates Melitus. Departemen Kesehatan Republik Indonesia. Jakarta.

Anonim. (2014). InfoDATIN: Pusat Data dan Informasi Kementrian Kesehatan RI. Kementrian Kesehatan Republik Indonesia. Jakarta.

Dipiro, T. Joseph. (2005). Pharmacotherapy. A Pathophysiologic Approach, $6^{\text {th }}$ Edition. McGRAW-HILL. New York.

Firdous, M., Koneri, R., Sarvaraidu, C.H., dan Shubhapriya, K.H. (2009). NIDDM Antidiabetic Activity Of Saponins Of Momordica Cymbalaria In Streptozotocin-Nicotinamide NIDDM Mice. Journal of Clinical and Diagnosis Research3: 1460-1465.

Harbone. (1987). Tumbuhan Berguna Indonesia (Vol. III). Badan Litbang Kehutanan. Jakarta.

Hembing W. (2004). Bebas Diabetes Ala Hembing. Puspaswara.

Imam, Zafar Mohammad., and Akter, S. (2011). Musa paradisiaca L. and Musa sapientum L.: A Phytochemical and Pharmacological Review.Journal of Applied Pharmaceutical Science. 01 (05), 14-20.

Malole, M. B. M., \& Pramono, C. S. U. (1989). Penggunaan Hewan-Hewan Percobaan dalam Laboratorium. Departemen Pendidikan dan Kebudayaan Direktorat Jendral 
Pendidikan Tinggi Antar Universitas, Bioteknologi, IPB. Bogor.

Peni, Sri. (2012). Uji Efek Hipoglikemik Ekstrak Air Kulit Buah Pisang Ambon Putih [Musa (AAA GROUP)] Terhadap Mencit Model Hiperglikemik Galur Swiss Webster. Prosiding SNaPP2012: Sains, Technologi dan Kesehatan. 3(1), 7380.
Szkudelski. (2001). The Mechanism of Alloxan and Streptozotocin Action in B Cells of the Rat Pankreas. Departement of Animal Physiology and Biochemistry, University of Agriculture. Poland.

Widowati, Wahyu. (2008). Potensi Antioksidan Sebagai Antidiabetes. JKM. 7 (2), 1-10. 